\title{
The Role of Antibodies in Acute Vascular Rejection of Pig-to-Baboon Cardiac Transplants
}

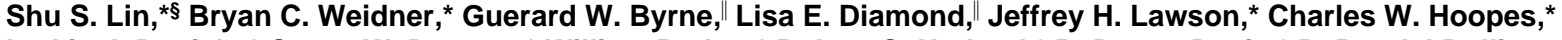 \\ Larkin J. Daniels, ${ }^{\star}$ Casey W. Daggett, ${ }^{*}$ William Parker, ${ }^{*}$ Robert C. Harland, ${ }^{*}$ R. Duane Davis, ${ }^{*}$ R. Randal Bollinger, ${ }^{\star}$ \\ John S. Logan, $\|$ and Jeffrey L. Platt ${ }^{\star \ddagger}$ \\ *Department of Surgery, ${ }^{\ddagger}$ Department of Pediatrics, and ${ }^{\S}$ Department of Immunology, Duke University Medical Center, Durham, North \\ Carolina 27710; and ${ }^{\|_{N}}$ extran, Princeton Forrestal Center, Princeton, New Jersey 08540
}

\begin{abstract}
Long-term success in xenotransplantation is currently hampered by acute vascular rejection. The inciting cause of acute vascular rejection is not yet known; however, a variety of observations suggest that the humoral immune response of the recipient against the donor may be involved in the pathogenesis of this process. Using a pig-to-baboon heterotopic cardiac transplant model, we examined the role of antibodies in the development of acute vascular rejection. After transplantation into baboons, hearts from transgenic pigs expressing human decay-accelerating factor and CD59 underwent acute vascular rejection leading to graft failure within $5 \mathrm{~d}$; the histology was characterized by endothelial injury and fibrin thrombi. Hearts from the transgenic pigs transplanted into baboons whose circulating antibodies were depleted using antiimmunoglobulin columns (Therasorb, Unterschleisshein, Germany) did not undergo acute vascular rejection in five of six cases. Biopsies from the xenotransplants in Ig-depleted baboons revealed little or no IgM or IgG, and no histologic evidence of acute vascular rejection in the five cases. Complement activity in the baboons was within the normal range during the period of xenograft survival. In one case, acute vascular rejection of a xenotransplant occurred in a baboon in which the level of antidonor antibody rose after Ig depletion was discontinued. This study provides evidence that antibodies play a significant role in the pathogenesis of acute vascular rejection, and suggests that acute vascular rejection might be prevented or treated by therapies aimed at the humoral immune response to porcine antigens. (J. Clin. Invest. 1998. 101:1745-1756.) Key words: heterologous transplantation (xenotransplantation) - heterophile antibodies (xenoreactive antibodies) • graft rejection $\bullet$ swine $\bullet$ papio
\end{abstract}

\section{Introduction}

Clinical application of transplantation is severely limited by the availability of organ donors. According to some estimates,

Address correspondence to Jeffrey L. Platt, M.D., Department of Surgery, Duke University Medical Center, Box 2605, Durham, NC 27710. Phone: 919-681-3857; FAX: 919-681-7263; E-mail: platt001@ mc.duke.edu

Received for publication 25 October 1997 and accepted in revised form 7 February 1998.

J. Clin. Invest.

(C) The American Society for Clinical Investigation, Inc. 0021-9738/98/04/1745/12 \$2.00

Volume 101, Number 8, April 1998, 1745-1756

http://www.jci.org as few as $5-10 \%$ of transplants that might be carried out are performed. The use of organs from a lower mammal, such as the pig, for clinical transplantation (xenotransplantation) has been recently considered as a potential solution to this problem. However, the use of porcine organs for this purpose is prevented by severe and unremitting rejection reactions that lead to destruction of the xenograft. The earliest type of rejection seen in a pig-to-primate xenograft is hyperacute rejection, which occurs within minutes to hours of transplantation (1-3) and is initiated by xenoreactive antibodies that bind to the endothelial lining of the graft vasculature, activating the complement system $(2,3)$. Hyperacute rejection can now be overcome by depletion of antidonor antibodies or inhibition of complement (3-5). When hyperacute rejection is averted, especially by inhibition of the recipient's complement system, the xenograft becomes subject to acute vascular rejection that destroys the graft over a period of hours to days $(6,7)$. This type of rejection is now viewed as a major immunologic barrier to the clinical application of xenotransplantation.

Although acute vascular rejection might be considered to be a delayed form of hyperacute rejection (8), there is much evidence that acute vascular rejection is distinct from hyperacute rejection (9). First, acute vascular rejection is observed in allografts and concordant xenografts in which hyperacute rejection normally does not occur (10-14). Second, the pathology of acute vascular rejection, which is characterized by endothelial swelling, focal ischemia, and diffuse microvascular thrombosis consisting mainly of fibrin $(6,14)$, differs from the pathology of hyperacute rejection, which is characterized by interstitial hemorrhage and platelet microthrombi $(15,16)$. Third, while the pathogenesis of acute vascular rejection is generally thought to reflect activation of endothelial cells in the transplant $(6,17,18)$, the course of hyperacute rejection proceeds too rapidly to allow the most significant effects of endothelial cell activation to be manifest. Fourth, acute vascular rejection develops when the complement system of the recipient is inactivated $(6,7)$, a condition that invariably precludes the development of hyperacute rejection $(19,20)$.

While acute vascular rejection may be related pathogenetically to the activation of graft endothelial cells, the events that incite endothelial cell activation are subject to controversy. Some have proposed that acute vascular rejection is caused by biological processes that would occur independently of the immune reaction of the host against the graft (8). On the other hand, we have proposed that while biological incompatibility might add to the severity, acute vascular rejection is triggered by persistent interaction of xenoreactive antibodies with the xenograft, as suggested by four lines of evidence (9): (a) patients exposed to porcine antigens from extracorporeal circulation through porcine livers experience an increase in the titer of xenoreactive antibodies within a few days, coinciding with the time when a xenograft is subject to acute vascular rejec- 
tion, and suggesting that immune stimulation has occurred $(21)$; (b) primates from which xenografts are removed after rejection have a sudden increase in antidonor antibody levels $(22,23)$, implying that the xenograft was continually exposed to xenoreactive antibodies; $(c)$ acute vascular rejection of allografts and concordant xenografts is associated with the presence of antidonor antibodies in the blood, or can be induced by administration of antidonor antibodies (10, 24, 25); and $(d)$ cytotoxic agents such as cyclophosphamide that inhibit the synthesis of antibodies appear to delay or avert acute vascular rejection (4).

We investigated the role of xenoreactive antibodies in the pathogenesis of acute vascular rejection by asking whether depletion of antibodies from a xenograft recipient would delay or prevent the manifestations of this process. Since the specificity of the xenoreactive antibodies that might be involved in acute vascular rejection is not characterized at this time, we depleted all antibodies using columns bearing anti-human Ig antibodies, sparing much of the other plasma proteins to test the extent to which the development and progression of acute vascular rejection would be changed.

\section{Methods}

\section{Animals}

Baboons (Papio anubis) were purchased from the Buckshire Corporation (Perkasie, PA). Pigs were transgenic for human decay-accelerating factor $(\mathrm{DAF})^{1}$ and $\mathrm{CD} 59$, expressing these proteins regulated constitutively by heterologous or homologous promoters. Development and characterization of the transgenic pigs used in this study were previously described in detail, and two transplants of hearts from these transgenic pigs into unmanipulated baboons were previously reported (26). The facilities in which the animals were housed were approved by the Association for Assessment and Accreditation of Laboratory Animal Care, and the studies were monitored and approved by the Animal Care and Use Committee of Duke University.

\section{Surgical procedures}

Harvesting donor organ. Hearts were harvested from anesthetized pigs using a standard technique (27). After isolation of the great vessels, the aortic root was cannulated, and the coronary arteries were perfused with cold $\left(4^{\circ} \mathrm{C}\right)$ University of Wisconsin solution to achieve cardiac arrest. Saline slush was applied topically to the heart, which was then resected and stored in saline slush as final preparation of the recipient was completed.

Recipient surgical procedures. Baboons were sedated with ketamine, intubated, and maintained under general anesthesia with isoflurane for all surgical procedures. For baboons undergoing depletion of antibodies before heterotopic cardiac xenotransplantation, splenectomy and insertion of a double-lumen Hickman catheter in the internal jugular vein were performed immediately before the first session of column treatment (see below). For baboons receiving the transplant without antibody depletion, splenectomy was performed on the day of xenotransplantation. Heterotopic cardiac xenotransplantation was performed as follows: through a lower midline abdominal incision, the infrarenal abdominal aorta and inferior vena cava were isolated, and the porcine heart was implanted by anastomosis of the donor aorta to the recipient abdominal aorta, and of donor pulmonary artery to the recipient inferior vena cava. In some cases, a

1. Abbreviation used in this paper: DAF, human decay-accelerating factor. right paramedian incision was made to expose the vessel through a retroperitoneal approach. In these instances, the porcine heart was revascularized using the recipient right common iliac artery and right common iliac vein if these vessels were thought to be of adequate size.

\section{Immunoglobulin depletion}

Immunoglobulin depletion was carried out by column absorption as follows: baboons were placed under general anesthesia, and were then connected via a double-lumen catheter Hickman $^{\mathrm{TM}}$; Baxter Healthcare Corp., Deerfield, IL) to the Autopheresis-C Therapeutic Plasmapheresis System ${ }^{\mathrm{TM}}$ (Unterschleissheim, Germany) which separates the plasma from the cellular components of whole blood. IgTherasorb $^{\mathrm{TM}}$ columns (Unterschleissheim, Germany), which contain polyclonal sheep anti-human IgG (heavy and light chain-specific) conjugated to Sepharose CL-4B were used in conjunction with the Adsorption-Desorption Automated machine ${ }^{\mathrm{TM}}$ (Baxter Healthcare Corp.) to absorb antibodies from the separated plasma. Two such columns were designed to work in parallel so that one column was absorbing antibodies from the plasma while the other column was being desorbed with $\mathrm{pH} 2.8$ glycine buffer and regenerated with $\mathrm{pH}$ 7.2 PBS solution. The absorbed plasma was recombined with blood cells and returned to the baboon through the Hickman catheter. Three to five plasma volumes were processed through the columns during each treatment session. For a given baboon, three to five sessions of Ig depletion were performed before transplantation, and two to three sessions per week were performed after transplantation for $2 \mathrm{wk}$ as described below.

\section{Immunosuppression}

Beginning with the day of the first session of Ig depletion, the baboons were treated with an immunosuppressive regimen consisting of methylprednisolone $(10 \mathrm{mg} / \mathrm{kg} / \mathrm{d})$ tapered by $1 \mathrm{mg} / \mathrm{kg} / \mathrm{d}$ to a maintenance dose of $1 \mathrm{mg} / \mathrm{kg} / \mathrm{d}, 5 \mathrm{mg} / \mathrm{kg} / \mathrm{d}$ cyclosporine following a loading dose of $15 \mathrm{mg} / \mathrm{kg}$, and $1-5 \mathrm{mg} / \mathrm{kg} / \mathrm{d}$ cyclophosphamide following a loading dose of $10 \mathrm{mg} / \mathrm{kg} / \mathrm{d}$ for 2-3 d. On the day of transplantation, the baboons were given a pulse dose of methylprednisolone at $10 \mathrm{mg} /$ $\mathrm{kg}$, which was again tapered by $1 \mathrm{mg} / \mathrm{kg} / \mathrm{d}$ to a maintenance dose of $1 \mathrm{mg} / \mathrm{kg} / \mathrm{d}$. In two cases (baboon nos. 6 and 7; see below), cyclophosphamide was started at $2 \mathrm{mg} / \mathrm{kg} / \mathrm{d}$ without a higher loading dose. The daily cyclosporine dosage was adjusted to maintain a blood cyclosporine level of 100-300 $\mathrm{ng} / \mathrm{ml}$, and the daily cyclophosphamide dosage was also varied to keep the white blood count between 1,000-4,000 cells per $\mathrm{mm}^{3}$.

\section{Porcine aortic endothelial cells}

Porcine aortic endothelial cells were explanted from porcine aortae and cultured in DMEM containing 10\% FCS, $2.0 \mathrm{mM}$ L-glutamine, $100 \mathrm{U} / \mathrm{ml}$ penicillin, and $100 \mu \mathrm{g} / \mathrm{ml}$ streptomycin as described previously $(28,29)$. The cells are known to express Gal $11-3 \mathrm{Gal}$, thought to be the predominant structure on porcine cells recognized by xenoreactive natural antibodies (30-32). As a target for the measurement of xenoreactive antibodies, the endothelial cells were cultured in 96-well plates (Becton Dickinson Labware; Lincoln Park, NJ; reference 29). After the endothelial cells reached confluence (3-7 d), they were fixed with $0.1 \%$ glutaraldehyde and frozen at $-80^{\circ} \mathrm{C}$ until needed.

\section{Quantitation of total protein levels}

The level of total protein in serum was determined using the BCA (bicinchoninic acid) protein assay (Pierce Chemical Co.; Rockford, IL). Plasma samples were serially diluted, incubated with the BCA reagent at $37^{\circ} \mathrm{C}$ for $30 \mathrm{~min}$, and the absorbance at $562 \mathrm{~nm}\left(\mathrm{~A}_{562}\right)$ was determined using an EL 340 Bio Kinetics Reader (Bio-Tek Instruments; Winooski, VT). The slope of the line in the linear range generated by plotting $\mathrm{A}_{562}$ vs. plasma concentration was taken as the relative concentration of total protein. A serially diluted sample containing known concentrations of BSA was applied to each plate as a standard to estimate the total protein concentration in the plasma. 


\section{Quantitation of total $\operatorname{IgM}, \operatorname{Ig} G$, and IgA levels}

Total immunoglobulin levels were determined by ELISA as follows. Nunc-Immuno Maxisorp polystyrene plates (VWR Scientific; Marietta, GA) were coated with $20 \mu \mathrm{g} / \mathrm{ml}$ of goat anti-human IgM, IgG, or IgA (Sigma Chemical Co., St. Louis, MO) for a minimum of $3 \mathrm{~h}$. The plates were then incubated with $1 \%$ BSA in PBS for $1 \mathrm{~h}$ to block nonspecific sites, and were washed with PBS. $50 \mu$ l of serially diluted serum or plasma (or PBS for background) were applied to wells in quadruplicate for $3 \mathrm{~h}$, washed three times with PBS, and incubated for $1 \mathrm{~h}$ with affinity-purified alkaline phosphatase-conjugated goat antibodies specific for human $\mu$-chain, $\gamma$-chain, or $\alpha$-chain (Sigma Chemical Co.). The wells were then washed four times with PBS, and $100 \mu \mathrm{l}$ of a developing solution consisting of $p$-nitrophenyl phosphate in a $100-\mathrm{mM}$ diethanolamine buffer was added. The absorbance at $405 \mathrm{~nm}\left(\mathrm{~A}_{405}\right)$ was determined using an EL 340 Bio Kinetics Reader. All steps in this assay were carried out at room temperature (22$25^{\circ} \mathrm{C}$ ). The slope of the line generated by plotting $\mathrm{A}_{405} \mathrm{vs}$. serum concentration was taken as the relative concentration of antibody. In some cases, the relative concentration of antibody was determined using one concentration of serum for which there was a linear relationship between the $\mathrm{A}_{405}$ and serum concentration. A serially diluted sample of a known standard was included on each plate to determine the absolute level of immunoglobulins. The concentrations of IgM, $\mathrm{IgG}$, and $\mathrm{IgA}$ in the standards were determined by nephelometry using a QM300 nephelometer (Sanofi, Chelsa, MN).

\section{Quantitation of xenoreactive and anti-Galo1-3Gal antibody levels}

The level of xenoreactive antibodies in serum or plasma was determined by ELISA using cultured porcine endothelial cells as previously described (29). Endothelial cells cultured in 96-well plates as described above were blocked with $1 \%$ BSA in PBS for $1 \mathrm{~h}$, and washed with PBS. The cells were then incubated with serum or plasma samples for $3 \mathrm{~h}$ at $4^{\circ} \mathrm{C}$, washed $3 \times$ with PBS, and incubated for $1 \mathrm{~h}$ at $25^{\circ} \mathrm{C}$ with affinity-purified alkaline phosphatase-conjugated goat antibodies specific for human $\mu$-chain or $\gamma$-chain. The wells were then washed, the developing solution was added, and the $\mathrm{A}_{405}$ was determined as described above. For determining the concentration of xenoreactive IgG in serum, IgM was inactivated by treating the serum with $10 \mathrm{mM}$ dithiothreitol (Sigma Chemical Co.; reference 33). The binding of $\operatorname{IgM}$ or IgG to Gal $1-3 \mathrm{Gal}$ was taken to be that binding eliminated by treating the cells with $\alpha$-galactosidase from green coffee beans (EC 3.2.1.22; Boehringer Mannheim Biochemicals; Indianapolis, IN) as described previously (34). The absolute concentration

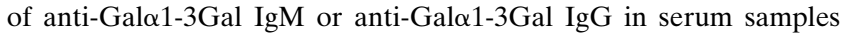
was determined by comparison with a standard consisting of human serum with a known concentration of the antibody $(33,35)$. The concentration of xenoreactive antibodies in serum expressed as $\mu \mathrm{g}$ of antibody per $\mathrm{ml}$ of serum was estimated by comparing the binding of xenoreactive antibodies with the binding of anti-Gal $\alpha 1-3 \mathrm{Gal}$ antibodies to porcine endothelial cells. Although this approach yields data that accurately reflects the relative amounts of binding of xenoreactive antibodies compared with anti-Gal $1-3 \mathrm{Gal}$ antibodies, it underestimates the absolute concentration of xenoreactive antibodies in serum since a fraction of xenoreactive antibodies are less avid than are antiGal 1-3Gal antibodies (36).

\section{Determination of complement activity}

The CH50 was measured by the lysis of sensitized sheep red blood cells (7). The $\mathrm{C} 3$ and $\mathrm{C} 4$ were determined by nephelometry using reagents specific for human $\mathrm{C} 3$ and $\mathrm{C} 4$ and known to react with the corresponding baboon proteins.

\section{Analysis of tissue sections}

A portion of each biopsy was fixed in $10 \%$ formalin solution for at least $24 \mathrm{~h}$. The fixed tissue was then dehydrated and embedded in a paraffin block. $4 \mu \mathrm{m}$-thick sections were cut and stained with hematoxylin and eosin.
Portions of each biopsy were snap-frozen in precooled isopentane and stored at $-80^{\circ} \mathrm{C}$ until use. Frozen tissue sections of $4-\mu \mathrm{m}$ thickness were prepared in a cryostat (Leica, Heidelberg, Germany). The sections were air-dried, fixed with acetone, and washed with PBS. Sections from each sample were incubated with affinity-isolated, FITCconjugated goat anti-human IgM ( $\mu$-chain specific; Kirkegaard \& Perry Laboratories, Inc., Gaithersburg, MD); affinity-isolated, FITCconjugated goat anti-human IgG ( $\gamma$-chain specific; Kirkegaard \& Perry Laboratories, Inc.); affinity-isolated, FITC-conjugated goat anti-human IgA ( $\alpha$-chain specific; Sigma Chemical Co.); affinity-isolated, FITC-conjugated goat antihuman C3 (Organon Teknika-Cappel, Durham, NC); affinity-isolated, FITC-conjugated goat antihuman C4 (Organon Teknika-Cappel); affinity-isolated, FITC-conjugated rabbit antihuman fibrinogen (Accurate Chemical and Scientific Corp., Westbury, NY); murine monoclonal antibody against human C5b neoantigen (Quidel; San Diego, CA); or murine monoclonal antibody against a neoantigen of the membrane attack complex (MBM5; generously provided by A.F. Michael, University of Minnesota [37] as described previously [38]). Tissue sections were then washed with PBS. Unlabeled murine monoclonal antibodies were detected with a double fluorochrome antibody layer consisting of affinity-isolated, $\mathrm{F}\left(\mathrm{ab}^{\prime}\right) 2$ FITC-conjugated goat anti-mouse IgG and affinity-isolated, $\mathrm{F}\left(\mathrm{ab}^{\prime}\right) 2$ FITC-conjugated rabbit anti-goat IgG (Organon TeknikaCappel). After the staining procedures, tissue sections were washed with PBS and mounted with $p$-phenylenediamine/glycerol solution (38). All antihuman reagents were shown to cross-react with their baboon counterparts. Background immunofluorescence was assessed by omitting the primary antibodies. Tissue sections were examined using a DMRB epifluorescence microscope (Leitz; Wetzlar, Germany) and photographed.

\section{Results}

Development of acute vascular rejection in baboons. After transplantation into baboons that had normal levels of xenoreactive natural antibodies, porcine hearts transgenic for human DAF and CD59 did not undergo hyperacute rejection, but were rejected over the ensuing hours to days by a process characteristic of acute vascular rejection (Table I) and consistent with prior observations $(26,39)$. Generally, cessation of beating was preceded by a period of about a day during which the cardiac xenograft was hyperkinetic. The pathology of these xenografts was characterized by endothelial cell swelling, diffuse vascular fibrin thrombi, focal ischemia, and deposition of IgM on the vascular endothelium, features typical of acute vascular rejection $(6,7)$. The immunopathology of the grafts revealed deposits of $\mathrm{C} 4$ and some $\mathrm{C} 3$ along blood vessels (like those of IgM described below), but no deposits of C5b or membrane attack neoantigens (not shown), suggesting effective regulation of complement by the human transgenes (26).

To provide a baseline for determining factors responsible for triggering acute vascular rejection, development of the pathological lesion was analyzed in serial biopsies (Fig. $1 \mathrm{~A}$, top). In biopsies from the xenograft in baboon no. 5, for example, thrombosis in microvascular lumena and endothelial cell swelling were observed as early as $24 \mathrm{~h}$ after reperfusion of the xenografts. Over the subsequent days, thrombosis became increasingly diffuse, affecting larger vessels. Histologic evidence of ischemia such as loss of $\mathrm{Z}$ bands and wavy characteristics of myocytes was apparent by day 5 , and was followed by focal ischemic necrosis. Other xenografts that underwent acute vascular rejection (baboon nos. 1-4) also developed this sequence of pathology, but in a more condensed time frame (Table I). Cellular infiltration was rarely observed in early biopsies; how- 


\begin{tabular}{|c|c|c|c|c|c|}
\hline \multirow[b]{2}{*}{ Baboon no. } & \multirow{2}{*}{$\begin{array}{c}\text { Baseline } \\
\text { [anti-Gal IgM] }\end{array}$} & \multicolumn{2}{|c|}{ No. of Ig depletion sessions } & \multirow{2}{*}{$\begin{array}{l}\text { Duration of } \\
\text { graft survival }\end{array}$} & \multirow{2}{*}{$\begin{array}{l}\text { Histologic } \\
\text { diagnosis }\end{array}$} \\
\hline & & Pretransplant & Posttransplant & & \\
\hline & $\mu g / m l$ & & & & \\
\hline \multicolumn{6}{|c|}{ Unmanipulated } \\
\hline 1 & 27.2 & none & none & $6 \mathrm{~h} *$ & AVR \\
\hline 2 & 34.2 & none & none & $11 \mathrm{~h}$ & AVR \\
\hline 3 & 17.4 & none & none & $1 \mathrm{~d}$ & AVR \\
\hline 4 & 3.9 & none & none & $3 \mathrm{~d}^{*}$ & AVR \\
\hline 5 & 16.2 & none & none & $5 \mathrm{~d}$ & AVR \\
\hline \multicolumn{6}{|l|}{ Ig-depleted } \\
\hline 6 & 10.8 & 5 & - & $1+\mathrm{d}^{\ddagger}$ & No AVR \\
\hline 7 & 17.4 & 4 & 2 & $5 d^{\S}$ & No AVR \\
\hline 8 & 34.7 & 4 & 3 & $7+d^{\ddagger}$ & No AVR \\
\hline 9 & 26.9 & 4 & $1^{\|}$ & $8 \mathrm{~d}$ & AVR \\
\hline 10 & 7.2 & 4 & 3 & 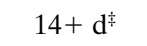 & No AVR \\
\hline 11 & 5.4 & 3 & 2 & $29 \mathrm{~d}^{\mathrm{I}}$ & No AVR \\
\hline
\end{tabular}

* These transplants were previously published (26). ${ }^{\ddagger}$ With a vigorously contracting xenograft, the recipient expired from complications of treatment with anti-Ig Therasorb columns (see text). ${ }^{\S}$ Graft loss did not appear to be due to acute vascular rejection or other immunologic event, as there was no evidence of antibody binding or complement deposition on the endothelium of the graft and no histologic evidence of hyperacute, acute vascular, or cellular rejection. "Immunosuppression was reduced, and second posttransplant Ig depletion was canceled due to severe thrombocytopenia. ${ }^{\mathrm{I}} \mathrm{Graft}$ loss due to infectious complications. AVR, acute vascular rejection.

ever, the emergence of ischemia was associated with a mild inflammatory infiltrate consisting primarily of neutrophils and macrophages. Among the five transplants carried out in this group of baboons, a total of twenty biopsies were analyzed: seven biopsies at $0.5-1 \mathrm{~h}$, seven at 6-24 h, five at days $2-3$, and one at day 5 .
Analysis of the immunopathology of these xenografts revealed progressive deposition of fibrin (Fig. $1 \mathrm{~B}$, top ). Immediately after reperfusion of the xenografts, fibrinogen was deposited in a normal pattern along lumenal surfaces of patent blood vessels. At $24 \mathrm{~h}$, fibrin thrombi were observed in lumena of small blood vessels. As acute vascular rejection progressed,

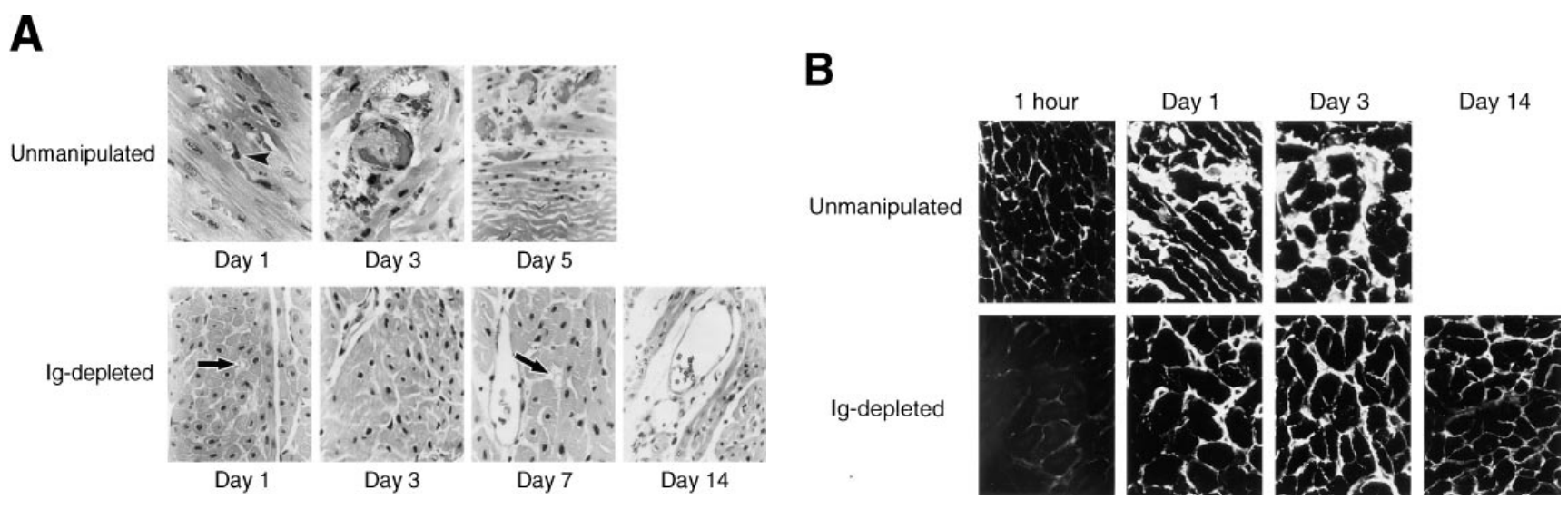

Figure 1. Development of acute vascular rejection in pig-to-baboon cardiac xenografts. Transgenic porcine hearts expressing human DAF and CD59 were transplanted heterotopically in baboons not treated (top) or treated (bottom) with anti-Ig Therasorb columns. Serial biopsies of the xenografts were analyzed by light microscopy for the presence of endothelial cell swelling, thrombosis, and focal ischemia and by immunofluorescence microscopy for staining with antifibrinogen/fibrin antibodies. (A) Histology. Histologic analysis of transgenic porcine hearts transplanted into baboons not treated with Ig depletion revealed endothelial cell swelling (arrowhead) and occlusive thrombi as early as $1 \mathrm{~d}$ after transplantation, progressing to diffuse thrombosis and ischemic necrosis at the time of rejection. In contrast, transgenic xenografts transplanted in Ig-depleted baboons had no evidence of endothelial damage, thrombosis, or ischemia. Vascular lumena remained patent (small vessels indicated by arrows), and myocytes appeared to be healthy. $(B)$ Deposition of fibrin. All xenografts displayed a normal vascular pattern of fibrinogen $1 \mathrm{~h}$ after reperfusion with recipient blood. As early as $1 \mathrm{~d}$ after transplantation, fibrin thrombi were observed in vascular lumena of xenografts in baboons not treated with Ig depletion. Over the subsequent days, the presence of fibrin thrombi was observed in the interstitium of these xenografts, presumably reflecting the loss of barrier function of endothelium. In contrast, transgenic xenografts transplanted into Igdepleted baboons had no significant formation of fibrin thrombi over time. The decreased intensity of fluorescence observed in the 1-h biopsy presumably reflects the transient state of hypofibrinogenemia in the baboon immediately after treatment with anti-Ig Therasorb columns. 


\section{$\ldots \ldots \ldots \ldots . . . . . \quad$ Total Ig \\ $\cdots \infty \cdots$ Xenoreactive $A b$ \\ $\longrightarrow$ Anti-Gala1-3Gal Ab}

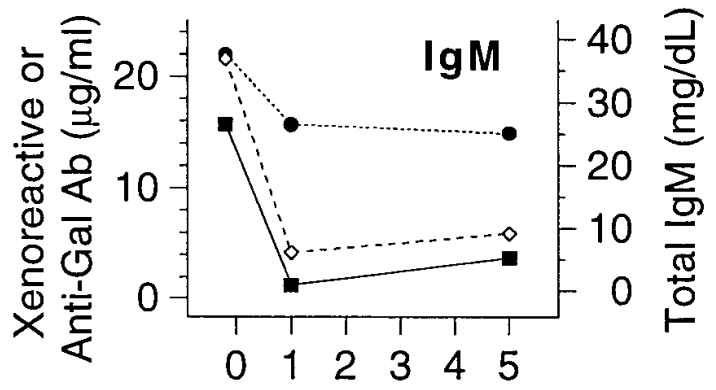

Day Number

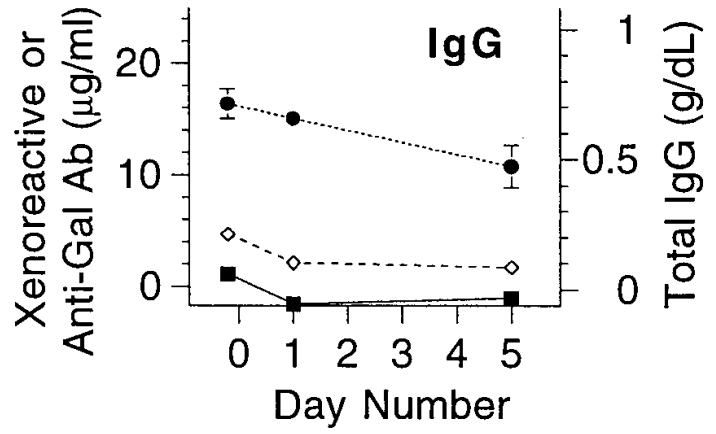

Figure 2. Xenoreactive antibodies and total Ig in baboons after cardiac xenotransplantation. Transgenic porcine hearts expressing human DAF and CD59 were transplanted heterotopically in baboons (not treated with Ig depletion). Serum from the baboons was tested at various times for total serum immunoglobulin $(\mathrm{Ig})$, xenoreactive antibodies, and anti-Gal $\alpha 1-3 \mathrm{Gal}$ antibodies as measured by ELISA. After xenotransplantation, total Ig in the serum was modestly lower than baseline, while xenoreactive antibodies and anti-Gal 1 1-3Gal $\operatorname{IgM}$ were profoundly decreased, presumably reflecting deposition of these antibodies in the graft. Significant levels of anti-Gal $\alpha 1-3 \mathrm{Gal}$ $\mathrm{IgG}$ were not detected. The standard errors are shown. leakage of fibrin into interstitium was observed, presumably reflecting loss of the barrier function of endothelium.

To evaluate the potential involvement of xenoreactive antibodies in the pathogenesis of acute vascular rejection, the levels of these antibodies in the blood of the recipients and in the xenografts were characterized in relation to the pathologic changes described above. Immediately after reperfusion of the xenografts, there was a decrease in the level of xenoreactive IgM in the blood (Fig. 2) and deposition of those antibodies in the graft (Fig. $3 A$, top), a result consistent with previous studies $(3,19,40)$. Anti-Gal 1 1-3Gal IgM in particular was undetectable in the blood of recipients after transplantation, confirming the idea that anti-Gal $\alpha 1-3 \mathrm{Gal}$ IgM is a major specificity of antibodies adsorbed by pig-to-primate xenografts, and is involved in the pathogenesis of hyperacute xenograft rejection (41). Absorption of xenoreactive IgM and anti-Gala1-3Gal IgM by the pig heart was specific, as the level of total IgM did not decrease significantly after transplantation. In some cases, anti-Gal 1 1-3Gal IgM was detected again at the time the xenograft underwent rejection (Fig. 2), perhaps reflecting a decrease in blood flow to the graft and/or saturation of the rejected xenograft with these antibodies.

The results observed for xenoreactive IgG were quite different than the results for xenoreactive IgM. Immunopathology of the xenograft showed that IgG deposition was absent or extremely weak, and the distribution of this staining was mostly interstitial and not associated with the vascular endothelium (Fig. 3 B, top). In addition, the drop in the level of xenoreactive $\mathrm{IgG}$ in the circulation after transplantation was not as dramatic as the reduction of xenoreactive IgM (Fig. 2, bottom). These findings are consistent with previous studies indicating that unsensitized nonhuman primates have little natural xenoreactive IgG and relatively low levels of anti-Gal $\alpha 1-3 \mathrm{Gal}$ IgG (41). Similarly, deposits of IgA were not detected in any of the xenografts (not shown).

Modification of baboon antibody level using anti-Ig Therasorb columns. To develop a model that would allow us to test the involvement of xenoreactive antibodies in the pathogenesis of acute vascular xenograft rejection, we used a method for
A

Unmanipulated
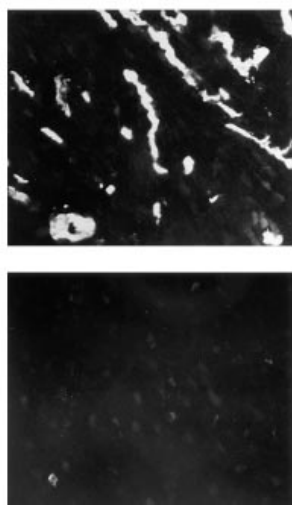

Day 3
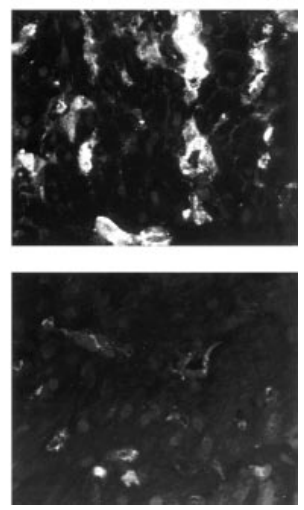

1 hour

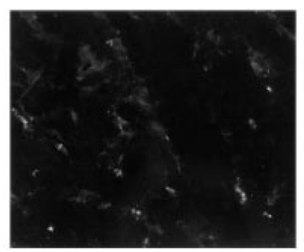

Ig-depleted

B

\section{Unmanipulated}

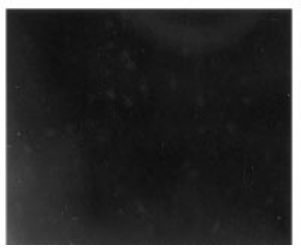

Day 3
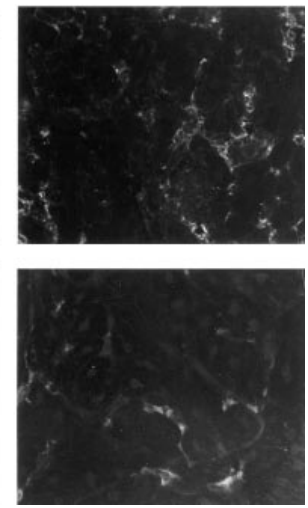

Figure 3. Deposition of IgM and IgG in porcine hearts transplanted into baboons. Transgenic porcine hearts expressing human DAF and CD59 were transplanted into baboons not treated (top) or treated (bottom) with anti-Ig Therasorb columns. Biopsies of the xenografts were analyzed by immunofluorescence microscopy for deposition of $\operatorname{IgM}$ and $\mathrm{IgG}$. (A) IgM. In baboons not treated with Ig depletion, IgM was deposited along the endothelial lining of blood vessels in the xenograft. In contrast, in baboons from which Ig was depleted, IgM was not detected in blood vessels in the xenograft. (B) IgG. Few or no deposits of IgG were observed along the endothelium of any of the xenografts analyzed. IgG fluorescence, when present, was mostly interstitial, suggesting nonspecific deposition in the graft. 


\section{A}

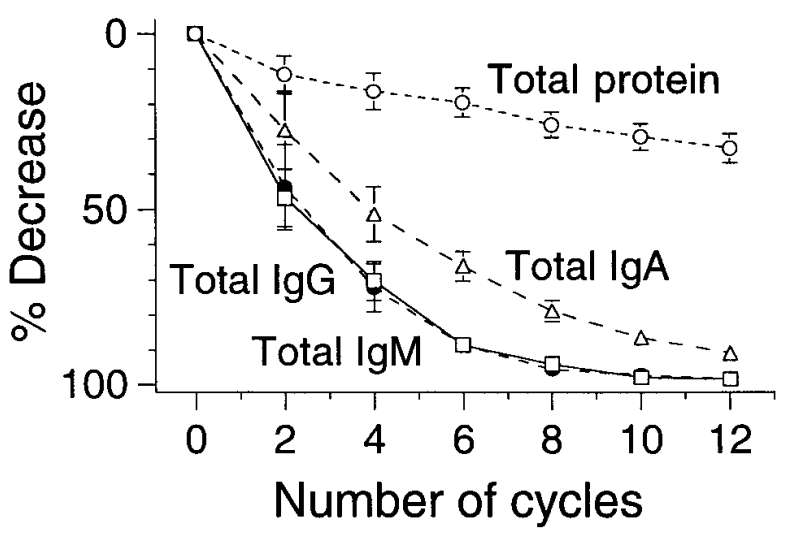

B

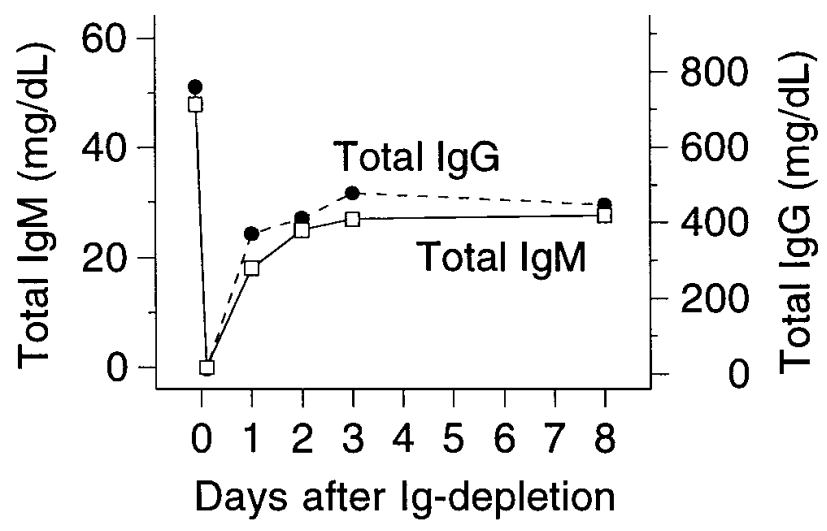

Figure 4. Changes in serum immunoglobulin and total protein levels in baboons during and after treatment with anti-Ig Therasorb columns. Baboons underwent plasmapheresis, and the separated plasma was passed through columns bearing anti-human Ig antibodies. The serum of the baboons was collected at various times, and total $\mathrm{IgG}$, total IgM, and total IgA levels were determined by ELISA and total protein level by colorometric assay. $A$ shows a decrease in the level of total $\mathrm{IgM}$, total $\mathrm{IgG}$, total $\mathrm{IgA}$, and total protein in baboons during treatment with anti-Ig Therasorb columns. Each cycle of Ig depletion consists of passing $\sim 260 \mathrm{ml}$ of separated plasma through a column containing $100 \mathrm{ml}$ of anti-human Ig-Sepharose beads followed by desorption as described in Methods. The absorbed plasma was recombined with blood cells and returned to the baboon. Changes in the levels of total $\mathrm{IgM}$, total $\mathrm{IgG}$, total $\mathrm{IgA}$, and total protein, with respect to the number of cycles of Ig depletion, were measured in four baboons and the mean $(n=4)$ of these changes plotted. After eight cycles of absorption, there was a $>90 \%$ depletion of total $\mathrm{IgM}$ and total $\mathrm{IgG}$, and a $>70 \%$ depletion of total $\mathrm{IgA}$ from the baboon circulation while a $20 \%$ decrease in the level of total protein occurred. All samples were analyzed in duplicates, and the standard errors are shown. $B$ shows an increase in total IgM and total IgG after Ig depletion in immunosuppressed baboons. After nearly complete depletion of $\mathrm{Ig}$ as shown above, IgM rose to $38 \%$ of the pretreatment level, and $\mathrm{IgG}$ rose to $50 \%$ of the pretreatment level within $24 \mathrm{~h}$. During the next $2 \mathrm{~d}$, IgM increased to $55 \%$ of the pretreatment level, and IgG increased to $60 \%$ of the pretreatment level, each remaining constant thereafter. The levels of total IgM and total IgG were analyzed at $8 \mathrm{~d}$ the depletion of all Ig from the circulation of baboons. Depletion of Ig was achieved by immunoabsorption of plasma with anti-Ig Therasorb columns in association with plasmapheresis. During each cycle of Ig depletion using anti-Ig Therasorb columns, $\sim 260 \mathrm{ml}$ of separated plasma was passed through 100 $\mathrm{ml}$ of Ig-Sepharose beads (Fig. $4 A$ ). Assuming that the plasma volume of a baboon is $5 \%$ of total weight, approximately 2.5 cycles would be needed to process one plasma volume of a 13$\mathrm{kg}$ baboon. The results shown in Fig. $4 \mathrm{~A}$ suggest that eight cycles of absorption $(2,080 \mathrm{ml}$ or $3.2 \mathrm{vol}$ of total plasma) were needed to achieve $>90 \%$ depletion of total $\mathrm{IgM}$ and $\mathrm{IgG}$ and $>70 \%$ depletion of total IgA. Treatment of the baboons with anti-Ig Therasorb columns led to a $20 \%$ decrease in the level of total protein. This reduction may have reflected some nonspecific adsorption to the columns and tubing, but was probably caused for the most part by dilution of plasma by priming of the extracorporeal circuit and fluid replacement during the procedure. Based on these initial data, a minimum of eight cycles of treatment corresponding to processing at least three times the total plasma volume, was used subsequently for each session of Ig depletion.

The therapeutic regimen used for Ig depletion involved repeated treatments, as clinical trials have demonstrated that repeated sessions of anti-Ig Therasorb column treatment are needed to deplete the extravascular pool of $\operatorname{Ig}(42)$. The timing of the repeated treatments was based on the kinetics of antibody increase (rebound or return of antibodies) after Ig depletion in baboons as illustrated in Fig. $4 B$, which shows that the minimum interval of time allowed for reequilibration of extravascular and intravascular pool of Ig should be $48 \mathrm{~h}$.

Outcome of xenograft transplants in Ig-depleted baboons. To explore the role of xenoreactive antibodies in acute vascular rejection, we tested the extent to which depletion of Ig from the recipient would influence the outcome of human DAF/CD59 transgenic xenografts in baboons. In contrast to the transplants in baboons that were not subjected to Ig depletion, five of six porcine cardiac transplants in Ig-depleted baboons did not undergo acute vascular rejection (Table I). Thus, xenografts in baboon nos. 6,8 , and 10 were still contracting when the recipients expired from various complications of therapy. Baboon nos. 6 and 10 died from pulmonary edema associated with anti-Ig column treatments. Baboon no. 8 died from hypotension caused by treatment of pulmonary edema. The histology and immunopathology of all of these xenografts revealed no evidence of endothelial injury, thrombosis, or ischemia. One xenograft (in baboon no. 7) ceased functioning on the fifth day after transplant. The cause of graft failure did not appear to be acute vascular rejection, and did not have an immunologic basis as there was no significant evidence of antibody deposition, complement activation, or cellular infiltrates. Another xenograft (in baboon no. 11) functioned for $29 \mathrm{~d}$, at which time contraction ceased due to complications of infection; bacterial thrombi were found within the blood vessels and in the interstitium. The xenograft in one Ig-depleted baboon (no. 9) did undergo acute vascular rejection. In this baboon, immunosuppression was reduced, and sessions of Ig de-

in one baboon as shown. The levels at earlier times were analyzed in all of the animals studied, and similar increases were seen (see Fig. 5). The immunosuppressive regimen is given in the Methods. 
Table II. Immunofluorescence Analysis of Fibrin Deposition in Xenografts at Various Times After Transplantation

\begin{tabular}{|c|c|c|c|c|c|c|}
\hline Xenograft recipient & $30 \mathrm{~min} \rightarrow 1 \mathrm{~h}$ & $6 \mathrm{~h} \rightarrow 24 \mathrm{~h}$ & day $2 \rightarrow$ day 3 & day $4 \rightarrow$ day 7 & day $8 \rightarrow$ day 14 & day 29 \\
\hline Unmanipulated & $\begin{array}{l}\text { Neg } \\
(n=7)\end{array}$ & $\begin{array}{l}2+-3+ \\
(n=7)\end{array}$ & $\begin{array}{l}2+-3+ \\
(n=5)\end{array}$ & $\begin{array}{c}4+ \\
(n=1)\end{array}$ & & \\
\hline Ig-depleted & $\begin{array}{c}\text { Neg } \\
(n=6)\end{array}$ & $\begin{array}{c}\text { Neg-tr }+ \\
(n=5)\end{array}$ & $\begin{array}{c}\mathrm{Neg}-\mathrm{tr}+ \\
(n=4)\end{array}$ & $\begin{array}{c}\text { Neg-tr }+ \\
(n=6)\end{array}$ & $\begin{array}{l}\text { Neg-tr }+ \\
(n=2)^{*}\end{array}$ & $\begin{array}{r}\text { Neg-tr }+ \\
(n=1)\end{array}$ \\
\hline
\end{tabular}

The number of fibrin thrombi per unit number of vessel profiles is estimated on a scale of negative (Neg) to $4+$ such that Neg $=$ no vessels per high power field, trace $(\operatorname{tr}+)=$ fewer than one vessel per high power field, and $4+=$ all vessels are involved. The range of results of each time period studied are shown. The number in the parentheses indicates the number of biopsies analyzed. *Results for baboon no. 9, which did not undergo Ig-depletion after day 6 , are not shown.

pletion were discontinued after the third day posttransplant because of severe thrombocytopenia development; the xenograft in this recipient ceased contracting on posttransplant day 8 , and the analysis of tissue from that day demonstrated histologic and immunohistologic features of acute vascular rejection. The biopsy tissue from day 3 revealed no evidence of this process.

The effects of Ig depletion on the progression of the tissue changes in acute vascular rejection were especially apparent from light microscopic analysis of serial biopsies obtained from xenografts transplanted into Ig-depleted baboons (Fig. $1 A$, bottom). None of the xenografts in Ig-depleted baboons exhibited the early tissue changes seen in acute vascular rejection. Thus, the vascular lumena remained patent with intact endothelium, and myocytes appeared healthy. Mononuclear cell infiltrates were not observed in the xenografts in Ig-depleted baboons. Polymorphonuclear cells were seen only in the final biopsy of the graft in baboon no. 11, presumably due to infection in the surrounding tissues. A total of 25 biopsies taken at various times from six transplants were analyzed. The biopsies were occasionally taken from multiple sites (usually left and right ventricles).

The extent to which fibrin thrombi were deposited in xenografts in Ig-depleted baboons was examined by immunopa- thology. Like the xenografts in baboons not subjected to Ig depletion, xenografts of Ig-depleted baboons had a normal baseline level of fibrinogen along vascular surfaces. However, in contrast to the xenografts in baboons with normal levels of xenoreactive antibodies, the xenografts in Ig-depleted baboons developed relatively few fibrin thrombi (Fig. $1 \mathrm{~B}$, bottom). A comparison of the distribution of fibrin thrombi present in the xenografts of unmanipulated and of Ig-depleted baboons is shown in Table II.

To confirm the effectiveness of anti-Ig columns in depleting antibodies relevant to the development of acute vascular xenograft rejection, we asked whether recipient Ig was deposited in the xenografts in Ig-depleted baboons. There was no significant deposition of IgM (Fig. 3 A, bottom) at any time in these xenografts. However, the xenograft in baboon no. 9, whose immunosuppression was reduced and Ig depletion discontinued on day 3 after transplantation, had significant deposits of $\operatorname{IgM}$. There were few or no IgG deposits in any of the xenografts analyzed, and the distribution of this staining, when present, was mostly interstitial and not associated with the vascular endothelium (Fig. 3 B, bottom). The intensity and distribution of $\mathrm{IgM}$ and $\mathrm{IgG}$ binding to the endothelium of xenografts are summarized in Table III.

Changes in the levels of antibodies in Ig-depleted baboons.

Table III. Immunofluorescence of Immunoglobulin Deposits on the Endothelium of Xenografts at Various Times after Transplantation

\begin{tabular}{|c|c|c|c|c|c|c|c|}
\hline Xenograft recipient & Ig isotype & $30 \mathrm{~min} \rightarrow 1 \mathrm{~h}$ & $6 \mathrm{~h} \rightarrow 24 \mathrm{~h}$ & day $2 \rightarrow$ day 3 & day $4 \rightarrow$ day 7 & day $8 \rightarrow$ day 14 & day 29 \\
\hline \multirow[t]{2}{*}{ Unmanipulated } & $\operatorname{IgM}$ & $\begin{array}{c}2+-3+ \\
\text { diffuse } \\
(n=7)\end{array}$ & $\begin{array}{c}2+-3+ \\
\text { diffuse } \\
(n=7)\end{array}$ & $\begin{array}{c}1+-2+ \\
\text { diffuse } \\
(n=5)\end{array}$ & $\begin{array}{c}2+ \\
\text { diffuse } \\
(n=1)\end{array}$ & & \\
\hline & $\operatorname{IgG}$ & $\begin{array}{c}\text { Neg-tr+ } \\
\text { focal } \\
(n=7)\end{array}$ & $\begin{array}{c}\text { Neg } \\
(n=7)\end{array}$ & $\begin{array}{c}\text { Neg-tr+ } \\
\text { focal } \\
(n=5)\end{array}$ & $\begin{array}{c}\operatorname{tr}+ \\
\text { focal } \\
(n=1)\end{array}$ & & \\
\hline \multirow[t]{2}{*}{ Ig-depleted } & $\operatorname{IgM}$ & $\begin{array}{c}\text { Neg-tr }+ \\
\text { diffuse } \\
(n=6)\end{array}$ & $\begin{array}{c}\text { Neg-1+ } \\
\text { focal } \\
(n=5)\end{array}$ & $\begin{array}{c}\text { Neg-tr }+ \\
\text { focal } \\
(n=4)\end{array}$ & $\begin{array}{c}\text { Neg-tr }+ \\
\text { focal } \\
(n=6)\end{array}$ & $\begin{array}{c}\text { Neg } \\
(n=2)^{*}\end{array}$ & $\begin{array}{c}\text { Neg } \\
(n=1)\end{array}$ \\
\hline & $\operatorname{IgG}$ & $\begin{array}{c}\text { Neg } \\
(n=6)\end{array}$ & $\begin{array}{c}\text { Neg-1+ } \\
\text { focal } \\
(n=5)\end{array}$ & $\begin{array}{c}\text { Neg-tr }+ \\
\text { focal } \\
(n=4)\end{array}$ & $\begin{array}{c}\text { Neg-tr }+ \\
\text { focal } \\
(n=6)\end{array}$ & $\begin{array}{c}\text { Neg-tr }+ \\
\text { focal } \\
(n=3)\end{array}$ & $\begin{array}{c}\text { Neg } \\
(n=1)\end{array}$ \\
\hline
\end{tabular}

Immunofluorescence was graded on a scale of intensity ranging from negative (Neg) to 4+. Distribution of Ig is indicated below. Shown are the range of results of each time period studied. The number in the parentheses indicates the number of biopsies analyzed. *Excluding baboon no. 9 that did not undergo Ig depletion after day 6 due to severe thrombocytopenia; the xenograft in this baboon showed $1+-2+\operatorname{IgM}$ staining on the endothelium at day 8. 

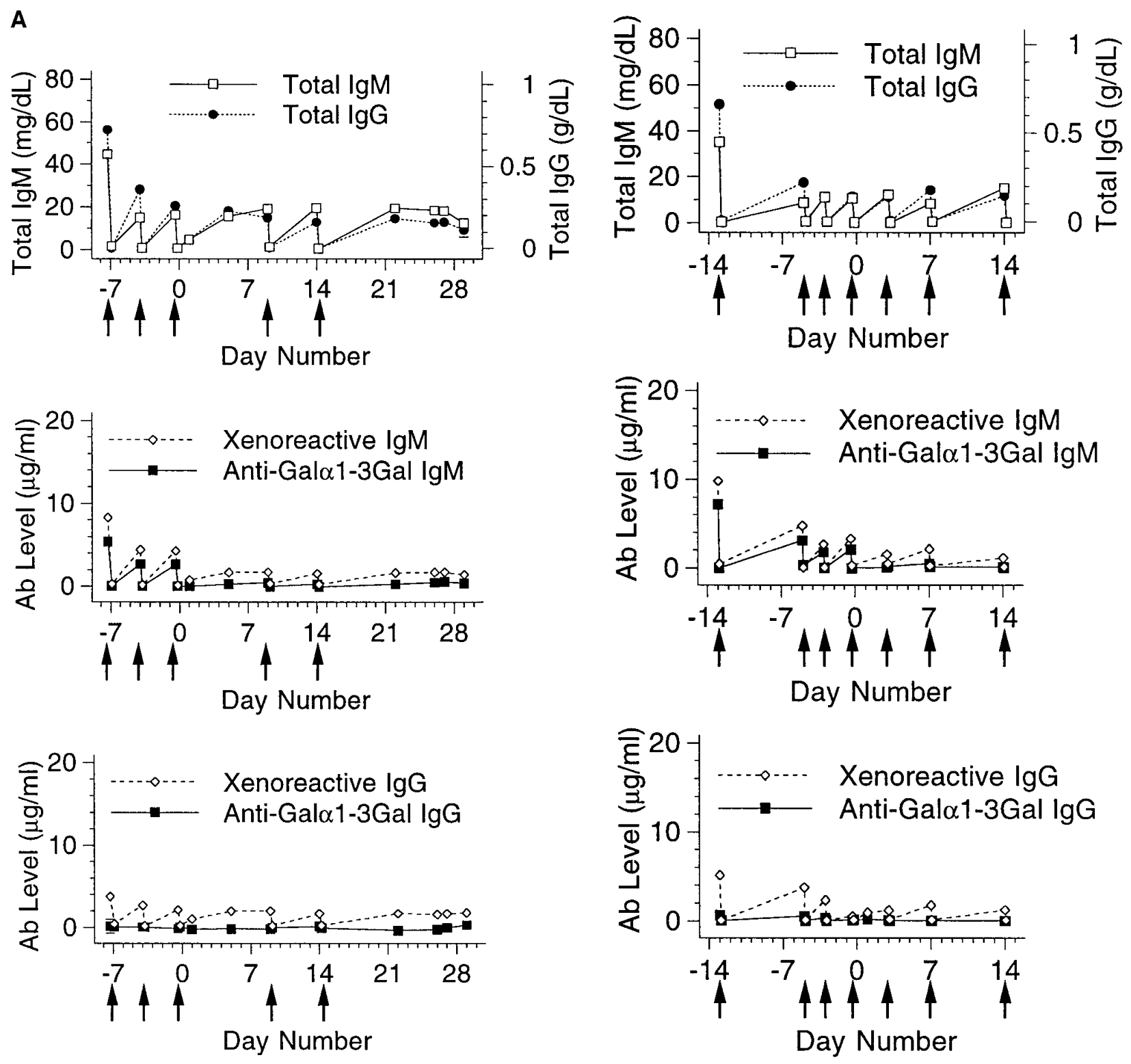

Figure 5. Changes in the levels of antibodies in Ig-depleted baboons before and after xenotransplantation. Blood was obtained from immunosuppressed baboons at various times before and after cardiac xenotransplantation, and total Ig, xenoreactive antibodies, and anti-Gal $\alpha 1-3 \mathrm{Gal}$ antibodies were measured by ELISA. Day 0 refers to the day of transplantation, and the solid arrows indicate when Ig depletion was performed. As illustrated in the examples shown in $A$ for baboon no. 11 and $B$ for baboon no. 10, total IgM in the circulation typically returned to $<40 \%$ of the pretreatment level after Ig depletion, while total IgG returned to $<30 \%$ of the pretreatment level. The level of total Ig was not significantly affected by the presence of the xenograft. However, the levels of xenoreactive IgM and anti-Gal $\alpha 1-3 \mathrm{Gal}$ IgM remained very low after xenotransplantation. Most of the baboons in this study, as represented in these two examples, had very low circulating levels of xenoreactive IgG, and almost undetectable circulating levels of anti-Gal $\alpha 1-3 \mathrm{Gal} \mathrm{IgG}$ at all times. The standard errors, all of which were $<1.1 \mathrm{mg} / \mathrm{dl}$ for total IgM, 0.05 $\mathrm{g} / \mathrm{dl}$ for total $\mathrm{IgG}, 0.4 \mu \mathrm{g} / \mathrm{ml}$ for xenoreactive and anti-Gal $\alpha 1-3 \mathrm{Gal} \mathrm{IgM}$, and $0.9 \mu \mathrm{g} / \mathrm{ml}$ for xenoreactive and anti-Gal $\alpha 1-3 \mathrm{Gal}$ IgG, are shown.

To investigate the extent to which a xenograft might be exposed to antidonor antibodies after Ig depletion, we measured the magnitude of the return of total Ig levels in Ig-depleted xenotransplant recipients (measurement of xenoreactive antibody levels after transplantation could not address this question as the circulating level of these antibodies is presumably affected by the presence of the graft). As illustrated in the examples shown in Fig. 5, total IgM in the circulation of Igdepleted baboons typically returned to no more than $40 \%$ of the original level, while total $\mathrm{IgG}$ approached $<30 \%$ of pretreatment levels. These results suggest that, to the extent that the level of xenoreactive antibodies respond like other anti- 


\section{$\ldots \rightarrow$ Xenoreactive $A b$ \\ $\longrightarrow$ Anti-Gala1-3Gal Ab}
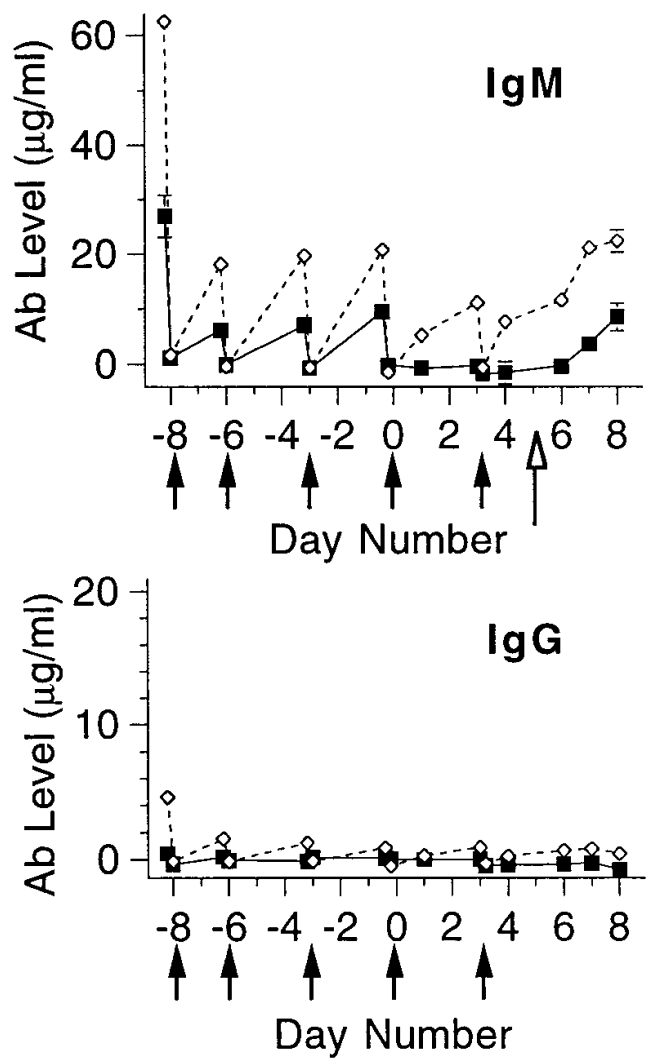

Figure 6. Levels of xenoreactive antibodies and anti-Gal $\alpha 1-3 \mathrm{Gal}$ antibodies in one Ig-depleted baboon (no. 9) in which a cardiac xenograft underwent acute vascular rejection. A porcine heart expressing human DAF and human CD59 was transplanted into a baboon that had been treated with Ig depletion. Column therapy were discontinued, and immunosuppression was reduced on day 3 after transplantation. Xenoreactive antibodies and anti-Gal $\alpha 1-3 \mathrm{Gal}$ antibodies were measured by ELISA. Day 0 refers to the day of transplantation, and the solid arrows show when Ig depletion was performed. The open arrow indicates the time when cyclophosphamide was terminated. The cardiac xenograft in this baboon ceased contracting on day 8 due to acute vascular rejection. The standard errors are shown.

bodies, xenoreactive antibodies are less available to react with the transplanted organ. As expected, the levels of xenoreactive antibodies in Ig-depleted baboons were very low after transplantation, and, in fact, anti-Gal $\alpha 1-3 \mathrm{Gal}$ antibodies were not detected (Fig. 5, middle and bottom). However, in the Igdepleted baboon (no. 9) in which acute vascular rejection occurred, the level of circulating anti-Galo1-3Gal IgM rose significantly at the time of rejection (Fig. 6).

One observation of potential interest is that the proportion of xenoreactive IgG that returned to the circulation after Ig depletion appeared to be greater than that of xenoreactive IgM, even during the period after transplantation. This finding suggests the possibility that a significant fraction of xenoreactive IgG detected by in vitro methods does not bind to porcine organs in vivo.
Serum complement activities after Ig depletion and transplantation. To determine whether some of the effects of Ig depletion on the development of acute vascular rejection might reflect depletion of complement rather than of Ig, complement levels were measured periodically after treatment and transplantation. Serum CH50 (Fig. 7), C3, and C4 (not shown) decreased transiently after treatment with anti-Ig Therasorb columns. This decrease coincided with and reflected at least in part the $\sim 20 \%$ transient dilution of plasma proteins. The CH50 returned to the baseline level within $9 \mathrm{~h}$ after the treatment. Complement activity remained normal, or was modestly increased thereafter, as documented while the xenograft was functioning (posttransplant days 1, 7, and 22).

\section{Discussion}

Acute vascular rejection is now widely viewed as the next and perhaps most recalcitrant hurdle to clinical application of xenotransplantation $(9,43)$. While various processes such as endothelial cell activation have been implicated in the pathogenesis of this lesion, a critical question remains regarding the event(s) that precipitate this process. The results reported here provide strong evidence that, of various potential factors postulated to trigger acute vascular rejection, including $\mathrm{T}$ lymphocytes (44), natural killer cells (45-47), and macrophages (18), antidonor antibodies are of preeminent import. Our findings further suggest a potential approach to preventing the devel-

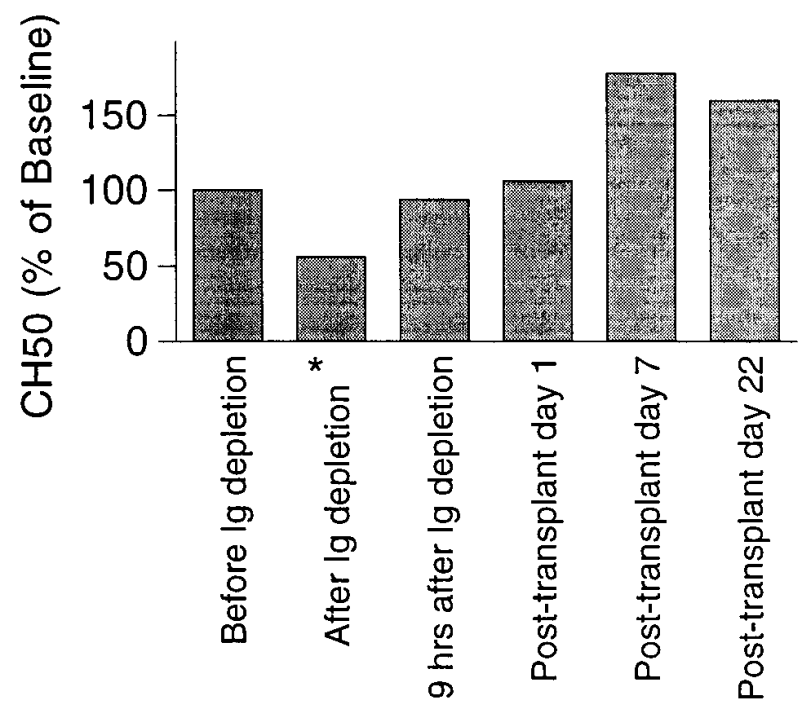

Figure 7. Serum complement activity in baboons after Ig depletion and transplantation with transgenic porcine hearts. Blood was obtained for measurement of serum complement activity at various times before and after Ig depletion and xenotransplantation in baboon no. 11. The transient decrease of serum complement activity to $<56 \%$ of the baseline level after treatment with anti-Ig Therasorb columns $(*)$ reflected at least in part an $\sim 20 \%$ dilution of plasma proteins caused by the return of the extracorporeal volume to the baboon. The $\mathrm{CH} 50$ returned to the baseline level within $9 \mathrm{~h}$ after the treatment. Complement activity remained normal or was modestly increased thereafter while the xenograft was functioning (days 1, 7, and 22 after transplant). Results shown are representative of results observed in all baboons studied. 
opment of acute vascular rejection, that is, pretransplant depletion of antidonor antibodies and maintaining a low level of these antibodies with appropriate immunosuppression. Indeed, this is the approach taken in clinical and experimental studies in which accommodation was first observed (48). Our results also raise the possibility that acute vascular rejection, when it occurs, might be treated, since posttransplant Ig depletion appeared to have had a beneficial effect on the xenograft.

The importance of antidonor antibodies in acute vascular rejection may explain why regimens that inhibit antibody synthesis, including administration of high doses of cyclophosphamide that are often not tolerated by the recipients, allow longterm survival of pig-to-primate xenografts (4). Even with the knowledge that antibodies are important in the development of acute vascular rejection, however, the optimal regimen for prevention and treatment has yet to be determined. Testing the role of antibodies in acute vascular rejection required the use of an apparatus that posed a physiologic challenge to the graft recipient. Clearly the method we used had a severe impact on the condition of the xenograft recipients, precluding long-term survival. As described in Results, the three baboons that expired had developed pulmonary edema after treatment with the anti-Ig columns. This complication may reflect the use of an extracorporeal circuit corresponding to a relatively large fraction (up to $\sim 50 \%$ ) of the intravascular plasma volume. However, Ig depletion has been successfully and safely performed on adult human subjects, so the problems encountered may likely reflect the smaller size of the baboons or the idiosyncrasies of the model, such as the requirement for anesthesia for each manipulation such as Ig-depletion. Based on the kinetics and the magnitude of antibody return after Ig depletion in this baboons model, we would anticipate that a schedule in which repeated sessions of Ig depletion are carried out before transplantation, with at least $48 \mathrm{~h}$ between consecutive sessions, might be optimal. Nevertheless, pretransplant depletion of antidonor antibodies alone may not be sufficient to prevent acute vascular xenograft rejection from occurring (23).

Given the very low level of xenoreactive antibodies detected in baboons after xenotransplantation, it would be reasonable to ask whether Ig depletion in the posttransplant period is needed. It is possible that clearing the circulation of all relevant antibodies, as it is done with anti-Ig Therasorb columns, might allow the dissociation and removal of antibodies already bound to the graft owing to a shift in the antibodyantigen equilibrium. Furthermore, our studies summarized in Figs. 5 and 6 do show a modest decrease in the level of circulating xenoreactive antibodies in Ig-depleted baboons after posttransplant Ig depletion. It is therefore possible that this set of xenoreactive antibodies that do not bind Gal $1-3 \mathrm{Gal}$ includes antibodies of pathogenetic import. It is also possible that lowaffinity antibodies that contribute to acute vascular rejection, whether or not they are specific for Gal 1-3Gal, might be depleted by anti-Ig Therasorb columns even though they are not detected in in vitro assays. Regardless of the mechanisms that may eventually be found, clinical studies in HLA-presensitized patients have documented beneficial effects of posttransplant antibody depletion, including reversal of humorally-mediated rejection of renal allografts (49-51).

If antidonor antibodies are important in the development of acute vascular rejection, how they trigger this rejection reaction is still uncertain. These antibodies might initiate acute vascular rejection by one or more of at least five mechanisms.
First, the binding of antibody to antigen may activate complement at a low level, leading to activation of graft endothelial cells. Activation of small amounts of complement can cause changes in the metabolism of endothelial cell heparan sulfate (52) and induction of tissue factor synthesis (53). Second, antidonor antibodies may directly perturb various functions of endothelial cells. The finding that carbohydrate substitutions on endothelial cell integrins are potential targets of xenoreactive antibodies could explain the loss of vascular integrity observed in rejecting xenografts (54). Third, antibody binding might deliver signals via endothelial cell integrins contributing to activation of graft endothelium (54). Fourth, antibody binding to endothelial antigens may facilitate the actions of effector cells via Fc receptors. For example, the bound antibodies may serve as a means for recognition by natural killer cells (45). Fifth, it is possible that xenoreactive antibodies, in binding to soluble antigens or antigens shed from endothelial cells (54), form intravascular immune complexes that precipitate a cascade of inflammatory and procoagulant activities seen in acute vascular rejection. Under this condition, the more severe injuries should be observed in proximity to the site of antigen release.

While the importance of antibodies in the development of acute vascular rejection is demonstrated here, the nature of the antibodies involved in this process is not revealed by these studies. We have previously found that anti-Gal $\alpha 1-3 \mathrm{Gal}$ antibodies initiate hyperacute rejection in the pig-to-baboon cardiac transplant model (41), and that the level of anti-Galo1$3 \mathrm{Gal}$ antibodies increases after xenotransplantation (23). These observations might provide clues regarding the specificity of the antibodies that trigger acute vascular xenograft rejection. Still, it is possible that xenoreactive antibodies not directed against the Gal $\alpha 1-3 \mathrm{Gal}$ epitope might contribute significantly to the pathogenesis of acute vascular rejection. This process may be caused by an increase in antibodies against an antigen that is expressed in low abundance, but which has considerable physiological importance. Such antigens might include elements of the cardiac conduction system or membrane channels (55). Consistent with this possibility, we have shown that among the antibodies detected in the serum after xenotransplantation, there are antibodies directed against an antigen expressed at low levels on the endothelial cell surface (23).

\section{Acknowledgments}

We thank Jamie Berthold, Meg Neal, Mike Milton, and Michelle Ekanayake for their assistance in surgical procedures, Mark Aujero and Mary Lou Everett for helping with the analysis of serum and plasma samples, and Pam Natvig for the preparation of tissues for histologic and immunohistologic examinations. We also thank Mr. Franz Birner and Dr. Robert Koll of Therasorb Medizinische Systeme $\mathrm{GmBH}$ (Unterschleissheim, Germany) for their advice in the technical aspects of the immunoglobulin depletion procedures.

This work was supported by grants from the National Institutes of Health (HL50985 and HL52297), and from Nextran. Shu S. Lin is a recipient of the American Society of Transplant Surgeons-Roche Surgical Scientist Award.

\section{References}

1. Alexandre, G.P.J., P. Gianello, D. Latinne, M. Carlier, A. Dewaele, L. Van Obbergh, M. Moriau, E. Marbaix, J.L. Lambotte, L. Lambotte, and J.P. Squifflet. 1989. Plasmapheresis and splenectomy in experimental renal xenotransplantation. In Xenograft 25. M.A. Hardy, editor. Elsevier Science Inc., New York. 259-266. 
2. Cooper, D.K.C., P.A. Human, G. Lexer, A.G. Rose, J. Rees, M. Keraan, and E. Du Toit. 1988. Effects of cyclosporine and antibody adsorption on pig cardiac xenograft survival in the baboon. J. Heart Transpl. 7:238-246.

3. Platt, J.L., R.J. Fischel, A.J. Matas, S.A. Reif, R.M. Bolman, and F.H. Bach. 1991. Immunopathology of hyperacute xenograft rejection in a swineto-primate model. Transplantation. 52:214-220.

4. Cozzi, E., N. Yannoutsos, G.A. Langford, G. Pino-Chavez, J. Wallwork, and D.J.G. White. 1997. Effect of transgenic expression of human decay-accelerating factor on the inhibition of hyperacute rejection of pig organs. In Xenotransplantation: the Transplantation of Organs and Tissues Between Species. D.K.C. Cooper, E. Kemp, J.L. Platt, and D.J.G. White, editors. Springer-Verlag, Berlin. 665-682.

5. Pascher, A., C. Poehlein, M. Storck, R. Prestel, J. Mueller-Hoecker, D.J.G. White, D. Abendroth, and C. Hammer. 1997. Immunopathological observations after xenogeneic liver perfusions using donor pigs transgenic for human decay-accelerating factor. Transplantation. 64:384-391.

6. Leventhal, J.R., A.J. Matas, L.H. Sun, S. Reif, R.M. Bolman III, A.P. Dalmasso, and J.L. Platt. 1993. The immunopathology of cardiac xenograft rejection in the guinea pig to rat model. Transplantation. 56:1-8.

7. Magee, J.C., B.H. Collins, R.C. Harland, B.J. Lindman, R.R. Bollinger, M.M. Frank, and J.L. Platt. 1995. Immunoglobulin prevents complement mediated hyperacute rejection in swine-to-primate xenotransplantation. J. Clin. Invest. 96:2404-2412.

8. Bach, F.H., H. Winkler, C. Ferran, W.W. Hancock, and S.C. Robson. 1996. Delayed xenograft rejection. Immunol. Today. 17:379-384.

9. Parker, W., S. Saadi, S.S. Lin, Z.E. Holzknecht, M. Bustos, and J.L. Platt. 1996. Transplantation of discordant xenografts: a challenge revisited. Immunol. Today. 17:373-378.

10. McPaul, J.J., P. Stastny, and R.B. Freeman. 1981. Specificities of antibodies eluted from human cadaveric renal allografts. J. Clin. Invest. 67:14051414.

11. Pedersen, N.C., and B. Morris. 1970. The role of the lymphatic system in the rejection of homografts: a study of lymph from renal transplants. J. Exp. Med. 131:936-969.

12. Reemtsma, K., B.H. McCracken, J.U. Schlegel, M.A. Pearl, C.W. Pearce, C.W. DeWitt, P.E. Smith, R.L. Hewitt, R.L. Flinner, and O. Creech. 1964. Renal heterotransplantation in man. Ann. Surg. 160:384-410.

13. Perper, R.J., and J.S. Najarian. 1966. Experimental renal heterotransplantation. II. Closely related species. Transplantation. 4:700-711.

14. Porter, K.A. 1992. Renal Transplantation. In Pathology of the Kidney. Vol. III. R.H. Heptinstall, editor. Little, Brown, and Company, Boston, MA. 1799-1933.

15. Lowenhaupt, R., and P. Nathan. 1968. Platelet accumulation observed by electron microscopy in the early phase of renal allotransplant rejection. $\mathrm{Na}$ ture. 220:822-825.

16. Rose, A.G., and D.K.C. Cooper. 1991. Ultrastructure of hyperacute rejection in cardiac xenografts. In Xenotransplantation. The Transplantation of Organs and Tissues Between Species. D.K.C. Cooper, E. Kemp, K. Reemtsma, and D.J.G. White, editors. Springer-Verlag New York Inc., New York. 243-252.

17. Platt, J.L., G.M. Vercellotti, A.P. Dalmasso, A.J. Matas, R.M. Bolman, J.S. Najarian, and F.H. Bach. 1990. Transplantation of discordant xenografts: a review of progress. Immunol. Today. 11:450-456.

18. Blakely, M.L., W.J. Van Der Werf, M.C. Berndt, A.P. Dalmasso, F.H. Bach, and W.W. Hancock. 1994. Activation of intragraft endothelial and mononuclear cells during discordant xenograft rejection. Transplantation. 58:10591066.

19. Gewurz, H., D.S. Clark, M.D. Cooper, R.L. Varco, and R.A. Good. 1967. Effect of cobra venom-induced inhibition of complement activity on allograft and xenograft rejection reactions. Transplantation. 5:1296-1303.

20. Miyagawa, S., H. Hirose, R. Shirakura, Y. Naka, S. Nakata, Y. Kawashima, T. Seya, M. Matsumoto, A. Uenaka, and H. Kitamura. 1988. The mechanism of discordant xenograft rejection. Transplantation. 46:825-830.

21. Cotterell, A.H., B.H. Collins, W. Parker, R.C. Harland, and J.L. Platt. 1995. The humoral immune response in humans following cross-perfusion of porcine organs. Transplantation. 60:861-868.

22. Rydberg, L., T.D. Cairns, C.G. Groth, M.L. Gustavsson, E.C. Karlsson, E. Moller, M. Satake, A. Tibell, and B.E. Samuelsson. 1994. Specificities of human IgM and IgG anticarbohydrate xenoantibodies found in the sera of diabetic patients grafted with fetal pig islets. Xenotransplantation. 1:69-79.

23. McCurry, K.R., W. Parker, A.H. Cotterell, B.C. Weidner, S.S. Lin, L.J. Daniels, Z.E. Holzknecht, G.W. Byrne, L.E. Diamond, J.S. Logan, and J.L. Platt. 1997. Humoral responses in pig-to-baboon cardiac transplantation: implications for the pathogenesis and treatment of acute vascular rejection and for accommodation. Hum. Immunol. 58:91-105.

24. Perper, R.J., and J.S. Najarian. 1967. Experimental renal heterotransplantation. III. Passive transfer of transplantation immunity. Transplantation. 5: 514-533

25. Paul, L.C., F.H.J. Claas, L.A. van Es, M.W. Kalff, and J. de Graeff. 1979. Accelerated rejection of a renal allograft associated with pretransplantation antibodies directed against donor antigens on endothelium and monocytes. $N$. Engl. J. Med. 300:1258-1260.

26. Byrne, G.W., K.R. McCurry, M.J. Martin, S.M. McClellan, J.L. Platt, and J.S. Logan. 1997. Transgenic pigs expressing human CD59 and decay-accelerating factor produce an intrinsic barrier to complement-mediated damage. Transplantation. 63:149-155.

27. Schwartz, M.E., L. Podesta, M. Morris, L. Makowka, and C.M. Miller. 1991. Donor management, techniques and procurement. In The Handbook of Transplantation Management. L. Makowka, editor. R.G. Landes Co., Austin, TX. 44-71.

28. Ryan, U.S., and G. Maxwell. 1986. Isolation, culture and subculture of endothelial cells: mechanical methods. J. Tissue Culture Methods. 10:3-5.

29. Platt, J.L., M.A. Turman, H.J. Noreen, R.J. Fischel, R.M. Bolman, and F.H. Bach. 1990. An ELISA assay for xenoreactive natural antibodies. Transplantation. 49:1000-1001.

30. Collins, B.H., W. Parker, and J.L. Platt. 1994. Characterization of porcine endothelial cell determinants recognized by human natural antibodies. $X e$ notransplantation. 1:36-46.

31. Good, A.H., D.K.C. Cooper, A.J. Malcolm, R.M. Ippolito, E. Koren, F.A. Neethling, Y. Ye, N. Zuhdi, and L.R. Lamontagne. 1992. Identification of carbohydrate structures that bind human antiporcine antibodies: implications for discordant xenografting in humans. Transpl. Proc. 24:559-562.

32. Sandrin, M.S., H.A. Vaughan, P.L. Dabkowski, and I.F.C. McKenzie. 1993. Anti-pig IgM antibodies in human serum react predominantly with Gal $\alpha$ (1,3)Gal epitopes. Proc. Natl. Acad. Sci. USA. 90:11391-11395.

33. Yu, P.B., Z.E. Holzknecht, D. Bruno, W. Parker, and J.L. Platt. 1996. Modulation of natural $\operatorname{IgM}$ binding and complement activation by natural $\operatorname{IgG}$ antibodies. J. Immunol. 157:5163-5168.

34. Parker, W., J. Lateef, M.L. Everett, and J.L. Platt. 1996. Specificity of xenoreactive anti-gal $\alpha 1-3$ gal IgM for $\alpha$-galactosyl ligands. Glycobiology. 6:499-506.

35. Parker, W., D. Bruno, Z.E. Holzknecht, and J.L. Platt. 1994. Xenoreactive natural antibodies: isolation and initial characterization. J. Immunol. 153: 3791-3803.

36. Parker, W., P.B. Yu, Z.E. Holzknecht, K. Lundberg-Swanson, R.H. Buckley, and J.L. Platt. 1997. Specificity and function of "natural" antibodies in immunodeficient subjects: clues to B-cell lineage and development. J. Clin. Immunol. 17:311-321.

37. Falk, R.J., A.P. Dalmasso, Y. Kim, C.H. Tsai, J.I. Scheinman, H. Gewurz, and A.F. Michael. 1983. Characterization of a monoclonal antibody and immunohistochemical localization in renal disease. J. Clin. Invest. 72:560-573.

38. Platt, J.L., T.W. LeBien, and A.F. Michael. 1982. Interstitial mononuclear cell populations in renal graft rejection: Identification by monoclonal antibodies in tissue sections. J. Exp. Med. 155:17-30.

39. Pruitt, S.K., A.D. Kirk, R.R. Bollinger, H.C. Marsh, Jr., B.H. Collins, J.L. Levin, J.R. Mault, J.S. Heinle, S. Ibrahim, A.R. Rudolph, et al. 1994. The effect of soluble complement receptor type 1 on hyperacute rejection of porcine xenografts. Transplantation. 57:363-370.

40. Perper, R.J., and J.S. Najarian. 1966. Experimental renal heterotransplantation. I. In widely divergent species. Transplantation. 4:377-388.

41. Lin, S.S., D.L. Kooyman, L.J. Daniels, C.W. Dagget, W. Parker, J.H. Lawson, C.W. Hoopes, C. Gullotto, L. Li, P. Birch, et al. 1997. The role of natural anti-Gal 1 1-3Gal antibodies in hyperacute rejection of pig-to-baboon cardiac xenotransplants. Transplant Immunology. 5:212-218.

42. du Moulin, A., J. Muller-Derlich, F. Bieber, W.O. Richter, U. Frei, R. Muller, and R. Spaethe. 1993. Antibody-based immunoadsorption as a therapeutic means. Blood Purif. 11:145-149.

43. Kobayashi, T., S. Taniguchi, F.A. Neethling, A.G. Rose, W.W. Hancock, Y. Ye, M. Niekrasz, S. Kosanke, L.J. Wright, D.J.G. White, and D.K.C. Cooper. 1997. Delayed xenograft rejection of pig-to-baboon cardiac transplants after cobra venom factor therapy. Transplantation. 64:1255-1261.

44. Fryer, J., J.R. Leventhal, A. Dalmasso, S. Chen, P.A. Simone, J.J. Goswitz, N.J. Reinsmoen, and A.J. Matas. 1995. Beyond hyperacute rejection. Transplantation. 59:171-176.

45. Inverardi, L., M. Samaja, R. Motterlini, F. Mangili, J.R. Bender, and R. Pardi. 1992. Early recognition of a discordant xenogeneic organ by human circulating lymphocytes. J. Immunol. 149:1416-1423.

46. Hancock, W.W., M.L. Blakely, W. van der Werf, and F.H. Bach. 1993. Rejection of guinea pig cardiac xenografts post-cobra venom factor therapy is associated with infiltration by mononuclear cells secreting interferon-gamma and diffuse endothelial activation. Transplant. Proc. 25:2932.

47. Malyguine, A.M., S. Saadi, R.A. Holzknecht, C.R. Patte, N. Sud, J.L. Platt, and J.R. Dawson. 1997. Induction of procoagulant function in porcine endothelial cells by human NK cells. J. Immunol. 159:4659-4664.

48. Chopek, M.W., R.L. Simmons, and J.L. Platt. 1987. ABO incompatible renal transplantation: initial immunopathologic evaluation. Transpl. Proc. 19: 4553-4557.

49. Pretagostini, R., P. Berloco, L. Poli, P. Cinti, A. Di Nicuolo, P. De Simone, M. Colonnello, A. Salerno, D. Alfani, and R. Cortesini. 1996. Immunoadsorption with protein $\mathrm{A}$ in humoral rejection of kidney transplants. ASAIO J. 42:M645-M648.

50. Mastrangelo, F., R. Pretagostini, P. Berloco, L. Poli, P. Cinti, P. Patruno, L. Alfonso, L. Pompei, F. Carboni, S. Rizzelli, et al. 1995. Immunoadsorption with protein A in humoral acute rejection of kidney transplants: multicenter experience. Transplant. Proc. 27:892-895.

51. Persson, N.H., D. Bucin, H. Ekberg, R. Kallen, M. Omnell Persson, M. 
Simanaitis, G. Sterner, and P. Swedenborg. 1995. Immunoadsorption in acute vascular rejection after renal transplantation. Transplant. Proc. 27:3466.

52. Ihrcke, N.S., and J.L. Platt. 1996. Shedding of heparan sulfate proteoglycan by stimulated endothelial cells: evidence for proteolysis of cell surface molecules. J. Cell. Physiol. 168:625-637.

53. Saadi, S., R.A. Holzknecht, C.P. Patte, D.M. Stern, and J.L. Platt. 1995 Complement-mediated regulation of tissue factor activity in endothelium. $J$. Exp. Med. 182:1807-1814.
54. Holzknecht, Z.E., and J.L. Platt. 1995. Identification of porcine endothelial cell membrane antigens recognized by human xenoreactive antibodies. $J$. Immunol. 154:4565-4575.

55. Boutjdir, M., L. Chen, Z.H. Zhang, C.E. Tseng, F. DiDonato, W. Rashbaum, A. Morris, N. el-Sherif, and J.P. Buyon. 1997. Arrhythmogenicity of IgG and anti-52-kD SSA/Ro affinity-purified antibodies from mothers of children with congenital heart block. Circ. Res. 80:354-362. 